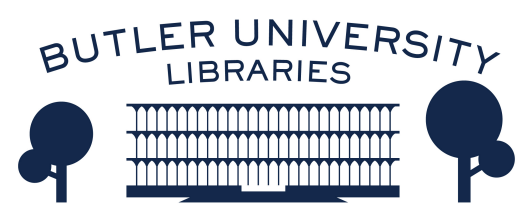

Volume 20

\section{Journal of Hindu-Christian Studies}

January 2007

\title{
Scholarship on Religion and Communities of Faith
}

Gerald James Larson

Follow this and additional works at: https://digitalcommons.butler.edu/jhcs

Part of the Religion Commons

\section{Recommended Citation}

Larson, Gerald James (2007) "Scholarship on Religion and Communities of Faith," Journal of HinduChristian Studies: Vol. 20, Article 10.

Available at: https://doi.org/10.7825/2164-6279.1385

The Journal of Hindu-Christian Studies is a publication of the Society for Hindu-Christian Studies. The digital version is made available by Digital Commons @ Butler University. For questions about the Journal or the Society, please contact cbauman@butler.edu. For more information about Digital Commons @ Butler University, please contact digitalscholarship@butler.edu. 


\title{
Scholarship on Religion and Communities of Faith
}

\author{
Gerald James Larson \\ Tagore Professor, Emeritus, Indiana University, Bloomington \\ Professor Emeritus, Religious Studies, UC, Santa Barbara
}

\begin{abstract}
(Due to a formatting error, part of this article was inadvertently omitted from its original appearance in the 2006 issue of the Journal of Hindu-Christian Studies. The article is now published in its entirety. The Journal of Hindu-Christian. Studies deeply regrets the error, and apologizes to Dr. Larson and our readers.)
\end{abstract}

WHEN I was asked to participate in this panel, two comments came to mind that, in my view, are pertinent for my own thinking regarding the issue of "Scholarship on Religion and Communities of Faith." . The first is E. M. Cioran's well-known comment many years back in Mircea Eliade's Festschrift. Says Cioran:

Is [Eliade] not one of the most brilliant representatives of a new alexandrianism...?

It is impossible to imagine a specialist in the history of religions praying. Or, if indeed [one] does pray, [one] thus betrays [one's] teaching...all the gods being viewed as equivalent. It is futile to describe them and comment upon them with insight...having tapped them of their sap, compared them with one another, and to complete their misery, frayed them with rubbing until they are reduced to bloodless symbols useless to the believer.... We are all of us, and Eliade in the fore, wouldhave-been-believers; we are all religious minds without religion. ${ }^{1}$

The second is the more recent remark by Peter Watson in his book, The Modern Mind: An Intellectual History of the Twentieth Century, explaining why his book has a "relative dearth" of non-Western thinkers. Says Watson:

I began to work my way through scholars who specialized in the major nonWestern cultures: India, China, Japan, southern and central Africa, the Arab world. I was shocked...to find that they all (I am not exaggerating, there were no exceptions) came up with the same answer, that in the twentieth century, the nonWestern cultures have produced no body of work that can compare with the ideas of the West.... I should make it clear that a good proportion of these scholars were themselves members of those very nonWestern cultures. ${ }^{2}$

GERALD JAMES LARSON is Rabindranath Tagore Professor Emeritus at Indiana University, Bloomington, and Professor Emeritus, Religious Studies, University of California, Santa Barbara. $\mathrm{He}$ is the author of numerous books and articles on Indian philosophy and comparative studies. Some of his recent books include Religion and Personal Law in Secular India: A Call to Judgment (Indiana University Press, 2001) and India's Agony over Religion (State University of New York Press, 1995). His most recent book, Yoga: India's Philosophy of Meditation, vol. XII of the Encyclopedia of Indian Philosophies, is being published by Motilal Banarsidass with the publication date of 2007. 
He continues:

Of course, there are important Chinese writers and painters in the twentieth century, and we can all think of important Japanese film directors, Indian novelists, and African dramatists... We have examined the thriving school of revisionist Indian historiography. Distinguished scholars from a non-Western background are very nearly household names-one thinks of Edward Said, Amartya Sen, Anita Desai or Chandra Wickramasinghe. But, it was repeatedly put to me that there is no twentieth century Chinese equivalent of, say, surrealism or psychoanalysis, no Indian contribution to match logical positivism.... Whatever list you care to make of twentieth century innovations, be it plastics, antibiotics, and the atom or stream-of-consciousness novels...or abstract expressionism, it is almost entirely Western. $^{3}$

The former comment by Cioran, referring to "...bloodless symbols useless to the believer," could probably now be inflated to something like "...symbolic interpretations...insulting to the believer." The latter comment by Watson; referring to the overwhelming preponderance of twentieth century Western intellectual influence throughout the non-Western world, touches, I am inclined to think, an important underlying reason for the vehemence of the response of the believer. This is the true not only in nonWestern contexts, I should perhaps hasten to add, but in Western contexts as well in which traditional believers are still to be found.

In any case, my task is to provide some sort of overview regarding these sorts of issues with respect to Hindu sensibilities. We are all familiar with the Kripal, Courtright and Laine cases, which are, of course, salient instances of the manner in which specific Hindu sensibilities have been aroused regarding the question of scholarship on religion and communities of faith. Arvind Sharma in a recent piece on the Laine case has put the matter in the following way:
The affair must be seen as part of a larger controversy over the study and representation of Hinduism as a whole. And that controversy is incomprehensible unless it is recognized that what we know about Hinduism's past derives almost exclusively from the work of Western scholars, whom some consider responsible for inventing "Hinduism" as a single religion.

Even today with Indian scholars also involved in the academic study of Hinduism, Western scholarship exercises a sway on the Indian mind out of all proportion to its size and in a way not comparable to its role in other religions. Indeed, in India Hinduism is still widely understood in Western terms-terms that include a highly negative perspective on its role in Indian public life and public education. ${ }^{4}$

While Arvind's comment is to some degree true, that is, that these conflicts must be seen in terms of a larger controversy over the representation of Hinduism in Western scholarship, there is also another player in the game of reactions by believers. That, of course, is the tradition of Islam in India. I did a quick survey of book-banning or controversies regarding the possibility of book-banning in India since independence, and what becomes immediately apparent is that the major controversies have to do with interactions between Hindu and Muslim communities. Secular Western scholarship has hardly been a factor until quite recently, that is, until the 1990s. Much more common is a book such as Arun Shourie, et al., Hindu Temples: What Happened to Them, Volumes I and II. ${ }^{5}$ Such works often contain venomous anti-Muslim polemic (and/or anti-Hindu polemic), and many books along these lines have been banned under Section 153A of the Indian Penal Code because they encourage enmity between community or religious groups. Salman Rushdie's work has come under this sort of ban as has the work of Taslima Nasreen, et al. In many of these cases, it should be noted, important intellectual voices in India such as Khushwant Singh, M. J. Akbar and Girilal Jain have concurred in the book- 
banning. I was also interested to learn that there have been extensive debates regarding TV serials such as the Ramayana, the Mahabharata and a TV sequence on Tipu Sultan. Claims have been made that all of these should have been banned because they fan the flames of communal hostility.

Stepping back, however, and taking a broader view of the unfolding Hindu scene, quite a different picture emerges. Prior to independence and continuing as well after independence there has been a vigorous and rich tradition of scholarship on religion in India directly linked to communities of faith. ${ }^{6}$ It is not possible within the framework of this short presentation to cover this rich tradition in detail, but let me highlight some of the salient features with a typology. I am inclined to identify four types of studies of religion among Hindu traditions that are closely linked to communities of faith. All are what I would refer to as "NeoHindu" traditions in the sense that all of the types that I shall mention are characterized by:

a) the use of English as a primary medium of communication,

b) a preference for modern education and scholarly methods rather than traditional methods,

c) the rejection of ritual-based hierarchies such as caste,

d) the self-confident assertion of the value and global importance of certain basic Hindu such as dharma, and so forth,

e) and the use of modern means of communication (published articles, books, pamphlets, tracts, films, videos, broadcasting, etc.).

By way of categorization, I would identify four types of Neo-Hindu scholarship on religion, namely:

Type I: Neo-Hindu Indological Studies of the ancient religion and cultures of India;

Type II: Neo-Hindu Reformist and Nationalist Studies

Type III: Neo-Hindu Revisionist and Internationalist Studies

Type IV: Neo-Hindu Diaspora Studies, with two sub-types

\section{Type IVA: Neo-Hindu Subaltern} Postmodernist Studies

Type IVB: Neo-Hindu Diaspora
Apologetics

Let me offer just a brief word about each type.

\section{Type I: Neo-Hindu Indological Studies.}

Here I have in mind the ground-breaking work of such giants as R. G. Bhandarkar (18371925)( in both Vedic and epic studies and the founding of the BORI), R. N. Dandekar (19092001)(again in Vedic and epic studies and for 54 years honorary director of the BORI), S. N. Dasgupta (1885-1952) in history of philosophy (along with to a lesser extent of importance S. Radhakrishnan and Jadunath Sinha), D. D. Kosambi (1876-1947) and his brilliant Marxian analyses of the epics, the Bhagavad Gita and bhakti tradtions generally and, of course, his younger colleague, Debiprasad Chattopadhyaya whose work on Carvaka and Tantra is still important, and, finally, in philosophy of religion studies, the work of Krishna Chandra Bhattacharya (1875-1949) and his son Kalidas Bhattacharya (1911-1984). Sometimes this body of work is called Orientalist, but none of us could do what we do in any of our work in Indian religion and philosophy without consulting these important intellectual ancestors.

\section{Type II: Neo-Hindu Reformist and Nationalist Studies.}

Here I have in mind such important figures and traditions as Rammohun Roy (1772-1833), the Brahmo Samaj (1825), the Prarthana Samaj (1867), the Arya Samaj (1875) and Dayananda Sarasvati (1827-1883), the Ramakrishna Mission (1897) and Swami Vivekananda (18621902), Aurobindo (1872-1956), D. Savarkar (1883-1966) and the Hindu Mahasabha and Hindutva, and, of course, Gandhi (1869-1948). ${ }^{7}$ All of these studies focus on (a) nationalist awareness, (b) reform of Hindu practices such as widow-burning, (c) rejection of caste, (d) female emancipation, (e) the "uplift of all" and/or the 
alleviation of poverty, and ( $f$ ) the use of modern means of propagation and communication.

\section{Type III: Neo-Hindu Revisionist and Internationalist Studies.}

Here, of course, are the many guru-groups and their various universal Hindu claims, including Swami Sahajananda (1781-1830), Swami Shiv Dayal (1818-1878), Paramahamsa Yogananda (1893-1952), Meher Baba (18941969), Bhaktivedanta (1896-1977), Muktananda (1908-1982) and his successor Gurumayi, Maharsi Mahesh Yogi (1911-) and Satya Sai Baba (1926-). These sorts of studies focus on (a) the centrality of the guru, (b) the need for total obedience to the guru, (c) the practice of one or another kind of Yoga, (d) the claim that all religions are basically one, (e) no need for a particular ethnic identity to belong-a Hindu spiritual vision that is universal, and ( $f$ ) the absence of a focus on social work or any kind of political activity.

\section{Type IV: Neo-Hindu Diaspora Studies.}

Here I have in mind mainly the Hindu diaspora community in the United States, and, as I see it, it appears that these sorts of studies clearly fall into two distinct divisions depending upon the social location of the diaspora discourse.

\section{Type IVA: Neo-Hindu Diaspora Subaltern Postmodernist Studies.}

This is an elitist, university-based, Hindu academic group of scholars, including Ranajit Guha, Gautam Bhadra, Dipesh Chakrabarty, Partha Chatterjee, Gyanendra Pandey, Gayatri Chakravorty Spivak, Homi Bhabha, et al., who have been instrumental in re-thinking (a) the historiography relating to India, and (b) attending to the "subaltern" voices in Indian culture and civilization. ${ }^{8}$. It appears to be heavily influenced by postmodernism and the new historicism of figures such as Frederic Jameson. I personally tend to see it as a kind of Neo-Orientalism. I am also frankly suspicious of this sort of scholarship. It is worrisome to me when elitist intellectuals, who occupy comfortable American university professorships, claim to speak for the poor masses of India.

\section{Type IVB: Neo-Hindu Diaspora Apologetics.}

This is probably the most recent type of Hindu studies. Its social location is equally as elitist as the Subaltern group, but it is not for the most part to be found in the academic community. Its social base is in diaspora urban communities all across the United States among Indian nationals who are engineers, IT professionals, business leaders, and medical professionals (physicians and surgeons). These appear to be people who are highly educated and sophisticated in their areas of expertise but for the most part have a somewhat limited academic training regarding the religious traditions and philosophies of India. They are, nevertheless, rightly proud of their heritage and are deeply troubled when they encounter studies of their religious tradition which appear to trivialize or demean their religious sensibilities (and rightly so, I would hasten to add). It is important for all of us in South Asian studies to recall that this concerned diaspora community has only begun to find its voice in the last ten years or so. In earlier years there were only the limited voices of the various internationalist spiritualist-groups (TM, Paramahamsa Yogananda, the Hari Krishna folks, the Swamis of the various Vedanta Societies, and so forth), most of which were not inclined to get involved in academic scholarly approaches to the study of religion.

But let me hasten to my conclusion. My purpose has been simply to give an overview of "scholarship on religion and communities of faith" with special reference to Hindu traditions. The contribution of Hindu scholars to the study of religion and philosophy in India has been massive and incredibly important for well over two hundred years. To be sure, much is owed to Western methods and ways of thinking deriving from the European Enlightenment, and there has been a long period of. Western intellectual hegemony that reaches down to the present moment. We are all aware now, however, that the universalist claims of Western thought are really only historically derived, and we are being 
questioned and criticized about that as never before. This need not be a negative event or process. As Western scholars we are being challenged to take a second look at what we have written and are writing about Hindu traditions. Likewise the diaspora community is having to deal with interpretations of their religious sensibilities that they are honestly unable to recognize. Vacaspatimisra, one of the great minds in Indian philosophy, referred to

\footnotetext{
Notes

1 E. M Cioran, "Beginnings of a Friendship," in Joseph M. Kitagawa and Charles H. Long, eds., Myths and Symbols: Studies in Honor of Mircea Eliade (Chicago: University of Chicago Press, 1969), pp. 253-254.

${ }^{2}$ Peter Watson, The Modern Mind: An Intellectual History of the Twentieth Century (New York: HarperCollins, 2001), pp. 761-762.

${ }^{3}$ Ibid.

${ }^{4}$ Arvind Sharma, "Hindus and Scholars," in Religion in the News, Spring (2004), Vol. 7, No. 1, p. 3.

${ }^{5}$ Arun Shourie, et al., (including Harsh Narain, Jay Dubashi, Ram Swarup, and Sita Ram Goel) Hindu Temples: What Happened to Them (Delhi: Voice of India Publications, 1991), passim.

${ }^{6}$ I have written about these traditions of scholarship at some length. See Gerald J. Larson, India's Agony over Religion (Albany: State University of New York Press, 1995), pp. 119-141.

${ }^{7}$ Ibid.

${ }^{8}$ Ibid., pp. 41-42.
}

anyonya-pratibimba, or the notion of "double reflection" wherein what appears becomes a distortion on both sides. I think that we are all becoming aware that something like that has been happening in our recent reactions to one another. As we try to sort out and clarify these distortions, we might be delightfully surprised to find some new and distinctive directions for our future work. 